\title{
Nicotine level associated with decreasing Treg number in smoker healthy volunteers
}

\author{
Akrom $^{1}$, Tri Julia Purnamasari ${ }^{2}$, Zaky Nurfaiz ${ }^{3}$, Adnan ${ }^{4}$, Endang Darmawan ${ }^{5}$, Muhammad Muhlis ${ }^{6}$ \\ ${ }_{1,4,5,6}$ Department Pharmacology and Clinical Pharmacy, Pharmacy Faculty, Universitas Ahmad Dahlan, Indonesia \\ ${ }^{1}$ Ahmad Dahlan Drug Information and Crisis Center, Indonesia \\ ${ }^{2,3}$ Magister Clinical Pharmacy Program, Pharmacy Faculty, Universitas Ahmad Dahlan, Indonesia
}

\begin{tabular}{l}
\hline Article Info \\
\hline Article history: \\
Received Jul 7, 2020 \\
Revised Dec 9, 2020 \\
Accepted Jan 2, 2021 \\
\hline
\end{tabular}

\section{Keywords:}

Cross-sectional study

Duration of smoking

Smoking behavior

Treg number nicotine level

\begin{abstract}
The intensity of cigarette exposure is associated with the severity of the inflammatory reaction. Treg cell plays a role in suppressing the inflammatory response. There has been no clear evidence on the relationship between smoker behavior with the nicotine level and Treg number. We will investigate the relationship between smoking behavior with the nicotine level and Treg number. We conducted a cross-sectional study of 106 healthy volunteers in Yogyakarta. We interviewed the subjects and took their blood samples for hemogram, Treg number, nicotine level, and blood chemistry examination. The inclusion criteria were fit, male or female, aged 18 years or older, and willing to volunteer proven by completing and signing the informed consent. We collected the data on smoking habits through interviews guided by a questionnaire. We examined hemogram and blood chemistry using a spectrophotometer, while the levels of nicotine were measured using The enzyme-linked immunosorbent assay (ELISA). We described the characteristics of the subjects by univariate analysis. The bivariate analysis was to determine the relationship between cigarette smoking length with nicotine level and Treg number. The results show a connection between the range of tobacco and cigarette number with nicotine levels in the blood with a value of $r=0.63$ in the Pearson correlation test $\mathrm{p}<0.00$. It can be concluded that there is a relationship between behavior smoking with nicotine levels and Treg counts.
\end{abstract}

This is an open access article under the $\underline{C C B Y-S A}$ license.



\section{Corresponding Author:}

\author{
Akrom \\ Department Pharmacology and Clinical Pharmacy \\ Pharmacy Faculty, Universitas Ahmad Dahlan, Indonesia \\ Email: akrom@pharm.uad.ac.id
}

\section{INTRODUCTION}

Smoking is a significant public health problem in Southeast Asia and Indonesia. Indonesia is the fourth-largest cigarette consuming country in the world [1]. The prevalence of smoking is $75 \%$ (57.6 million) among men and $2.9 \%$ (2.3 million) in women. Among the adult population, $62 \%$ of adult men (57.6 million), $1.7 \%$ of adult women (1.6 million), and $31.9 \%$ overall (50.3 million) are daily smokers [2]. The National Basic Health Research in 2016 showed that the average consumption of cigarettes per person (aged 15 years or above) was 12 sticks/day [3]. Tobacco smoke has been associated with many degenerative and infectious diseases, i.e., cancer, hypertension and cardiovascular disease, chronic obstructive pulmonary disease (COPD), asthma, diabetes mellitus, and end-stage renal disease (ESRD) [4, 5]. The cigarette contains many toxic and immunosuppressant agents, such as dimethylbenzanthracene (DMBA), benzopyrene, carbon 
monoxide, and nicotine [6, 7]. Excessive nicotine intake causes many organs and tissue disorders [8,9]. Health promotion to awaken smoking dangers based on scientific evidence is urgently conducted [10, 11].

Nicotine is a cigarette toxicant that causes cell damage. Exposure to smoke causes cell injury [12]. Cellular damage stimulates proinflammatory cytokine production. Proinflammation cytokines and reactive protein cause an increase in bone marrow activity [13]. The distribution and absorption of nicotine into the pulmonary circulation are swift [14]. Nicotine can penetrate the blood-brain barrier and affect the central nervous system within 20 seconds of inhaled cigarettes. In the acute phase of nicotine, stimulation causes the sympathetic nerves' activation and makes the condition vibrant and refreshed. In a short time (10 minutes of smoking), plasma nicotine peak is at 15 to $30 \mathrm{ng} / \mathrm{mL}$ [15]. Rapid pharmacological response from nicotine is assumed to be a critical factor in nicotine dependence. In the advanced phase, high levels of nicotine and reactive radicals and carcinogens have the opposite effect. In the routine smoker, who smokes frequently and continuously, the carboxy hemoglobin $(\mathrm{Hb})$ levels increase and produce progressive hypoxemia, and as the carbon monoxide $(\mathrm{CO})$ binds with $\mathrm{Hb}$, functional anemia is produced. Hypoxemia condition causes the impaired oxygenation of tissues and changes in biological parameters [16]. Nicotine, through nicotinic receptors and kinin-beta receptors, increases proinflammatory activity. The level of nicotine associate with the dependency and the impaired bodily functions level [17]. But it turns out nicotine metabolism in the body is influenced by ethnicity, so the plasma nicotine levels in smokers vary depending on race [8]. However, there are many studies on smoking behavior in Indonesia until now, and there has not been much research on smoking behavior related to plasma nicotine levels.

In previous studies, tobacco smoke and dimethylbenzanthracene are chronic disease risk factors and increase chronic disease prevalence in the population $[18,19]$. The chronic disease provides physically, economically, socially severe impacts for the patient, their family, and the government. Unfortunately, most chronic diseases (chronic kidney disease (CKD), cancer, diabetes mellitus) patients in Indonesia were detected late [20]. Chronic inflammation due to cigarette exposure causes glomerulosclerosis [21]. Glomerulosclerosis causes an ischemic condition in the nephron. The uncontrolled-acute ischemic injury will continue to become glomerulopathy and tubulopathy [22, 23]. Increased urea and creatinine levels were characteristics of impaired kidney function due to decreased glomerular filtration rate [24, 25]. A laboratory study has shown to control the inflammatory response to acute ischemic kidney damage in vivo. Treg is one of the immune system cells responsible for maintaining kidney damage's inflammatory reaction due to cigarette exposure $[26,27]$. We suspected that the number of Treg cells has decreased in chronic smokers, and creatinine levels have increased due to decreased glomerular function [28, 29]. Based on this background, this study aimed to determine the relationship between smoking behavior with nicotine levels and the amount of Treg.

\section{RESEARCH METHOD}

\subsection{Research design and variables}

This research was an analytic observational study with a cross-sectional design. The experiment was conducted in Special Region of Yogyakarta or Daerah Istimewa Yogyakarta (DIY), Indonesia, by taking a random proportional sample in five districts: Yogyakarta, Sleman, Bantul, Kulon Progo, and Gunungkidul. The independent variables consisted of demographic characteristics, weight, height, and smoking behavior. The dependent variable was nicotine level, Treg number, hemogram profile, and blood chemistry. We defined active smoking behavior as inhaling burning tobacco smoke and chewing tobacco and other tobacco products for the last five years. The smoker behavior was categorized as an active smoker or "YES" if the respondents have smoked more than 100 cigarettes in their lifetime; NO if the respondents did not meet the criteria. The respondents were categorized as former smokers (YES) if they had smoked more than 100 cigarettes in their lifetime but had stopped before the last five years. Nonsmokers were the respondents who did not smoke or had smoked but less than 100 cigarettes in their lifetime. We collected smoking behavior data through interviews supported by a questionnaire. We confirmed the data by the measurement of blood nicotine levels using ELISA. Treg level was the percentage of Treg (CD4+CD25+T lymphocytes) against total lymphocytes defined by flow cytometry.

\subsection{Subject}

The inclusion criteria were Indonesian (Javanese, Sundanese, and Malay), aged 18-65 years, healthy male/female, and willing to participate in the study by completing and signing informed consent and being cooperative. The subjects were patients with congenital kidney disease, history of kidney transplantation, mental illness, and growth disorder (dwarfis m/gigantism). Previous research has shown that the percentage of smokers in the community had reached $32 \%$ [5, 30]. We recruited 106 subjects, while the minimum number of research subjects was 102 . 


\subsection{Materials and research instruments}

We collected primary data used questionnaires, and secondary data used data collection forms. We determined the nicotine level by the ELISA method. We measured Treg levels with flow cytometry. We carried out a Treg examination at the clinical pathology laboratory of Medical Faculty, Universitas Gadjah Mada (UGM). We used the questionnaire to obtain primary data from respondents, and data collection form to collect secondary data, including name, age, and gender extracted from medical records.

\subsection{Research procedures}

\subsubsection{Subject recruitment procedure}

Patients were selected based on the inclusion and exclusion criteria. We collected 106 healthy volunteers with a high risk of chronic kidney disease from five regencies in DIY. The recruitment was adjusted to the number/proportion of chronic kidney disease patients undergoing hemodialysis in Bantul General Hospital, Yogyakarta Muhammadiyah Hospitals, and Red Cross Indonesia Clinics in Yogyakarta.

\subsubsection{Data collection method}

We collected the data through interviews and direct observation or measurements. Table 1 summarized the data types and their collection methods. Primary data were collected both in the field and in the clinic. We obtained the respondent's data habits and lifestyles using interviews guided by questionnaires and data collection forms. We collected smoking history data through a structured interview guidedquestionnaire. Data collected through the discussions include respondents' identity, socioeconomic status, marital status, education history, occupation, and smoking behavior data. We classified smoking behavior as no smoking, smoking, and former smoking. Primary data concerning the characteristics and clinical manifestations, as well as Treg levels, were obtained through direct measurements. We captured clinical data with a laboratory observation method. Clinical data collected by physical and laboratory examination include body mass index (BMI), peripheral blood hemogram, blood chemistry, and nicotine and Treg levels. The brief procedure was as follows: i) the weight and height of prospective subjects who have been fasting for 812 hours were measured to determine BMI. The potential Subjects had received an explanation about the purpose of the study. They were asked to sign informed consent as evidence of their agreement to participate in the study. The $5 \mathrm{ml}$ of blood was drawn from the volunteer's median cubital vein. A total of $3 \mathrm{ml}$ of blood was centrifuged at $3000 \mathrm{~g}$ for 15 minutes. The blood was used to measure blood sugar, triglycerides, creatinine, urea, nicotine, and Treg. ii) The levels of creatinine and urea were measured using a spectrophotometer. ELISA measured nicotine levels.

Table 1. Research data types and collection methods in healthy respondents in DIY

\begin{tabular}{lll}
\hline \multicolumn{1}{c}{ Data types } & \multicolumn{1}{c}{ Details } & \multicolumn{1}{c}{ Data collection method } \\
\hline Demographics & $\begin{array}{l}\text { Gender, age, address, place of birth, date of birth, employment } \\
\text { history, education history }\end{array}$ & $\begin{array}{l}\text { Data collection form and interviews } \\
\text { guided by questionnaires. }\end{array}$ \\
$\begin{array}{l}\text { Characteristics of the } \\
\text { Wubject, lifestyle, and } \\
\text { clinical manifestations }\end{array}$ & $\begin{array}{l}\text { urea and creatinine, random blood glucose levels, and duration of } \\
\text { smoking, weekly amount of tobacco packs; workplace and } \\
\text { environment (duration and intensity); history of smoking cessation } \\
\text { (first smoking cessation, length of smoking cessation) }\end{array}$ & $\begin{array}{l}\text { Direct examination of blood chemistry } \\
\text { was measured with spectrophotometry. } \\
\text { Struct ured interview guided by a } \\
\text { questionnaire. }\end{array}$ \\
$\begin{array}{l}\text { Smoking history and } \\
\text { nicotinelevels }\end{array}$ & Blood nicotine levels & $\begin{array}{l}\text { A direct examination of blood nicotine } \\
\text { levels using the ELISA method [31] }\end{array}$ \\
\hline
\end{tabular}

\subsection{Data analysis}

The data were processed and then presented descriptively, followed by bivariate analysis. One-way ANOVA compared the number of cells in Hemogram and Treg or levels in blood chemistry and nicotine levels among respondent smokers and nonsmokers with a 95\% significance level. The correlation between smoking habit (classification of the duration of smoking and number of packs/week cigarette consume) and nicotine level and Treg count was analyzed using Pearson correlation.

\subsection{Research ethics}

After being approved by the local Institutional Review Board, the study was conducted by following Good Clinical Practice: explaining to all potential subjects about the goal and objective of the research, the expected benefits and uses, the consequences for the subjects, and the rights and obligations of the subjects. The written informed consent form was obtained from each subject. The study protocol and interview guidelines have been reviewed and approved by the health research ethics committee, Medical Faculty of UGM (ref No: KE/FK/847/EC). 


\section{RESULTS DAN DISCUSSION}

\subsection{Subjects' characteristics}

Subjects have lived in five districts in DIY: Yogyakarta, Sleman, Bantul, Kulon Progo, and Gunungkidul. Tables 2 and 3 show the characteristics of the subject. Table 2 shows that the number of male subjects was twice the higher of females, i.e., 66.3\% compared to 33.7\%. Most subjects aged between 46-60 years $(50.3 \%)$, followed by $31-45$ years $(27 \%)$, >60 years $(18.2 \%)$, and $16-30$ years $(7.4 \%)$. Most subjects were senior high school graduates and working in the private sector.

In this cross-sectional study, the number of smokers $>30 \%$ of respondents, more than $20 \%$ of respondents smoked 20 or more 20 years, and $16 \%$ of respondents smoked 15 packs/week or more. This description is following the condition of smokers in Indonesia [32,33]. Table 3 presents an overview of clinical characteristics and the result of respondents' laboratory examinations. Blood pressure, BMI, hemoglobin levels, erythrocyte, leukocyte, random blood glucose level, urea level, and creatinine are normal. The mean of the nicotine level was $19.34 \mathrm{ng} / \mathrm{ml}$.

Table 2. Demographic characteristics and smoking behavior of healthy volunteers in DIY

\begin{tabular}{|c|c|c|c|}
\hline No & & Characteristics of respondents & Number (percentage) \\
\hline 1 & Gender & Men & $70(66.3 \%)$ \\
\hline \multirow[t]{3}{*}{2} & \multirow{3}{*}{ Age group } & $16-30$ years & $11(10.38 \%)$ \\
\hline & & $46-60$ years & $50(47.17 \%)$ \\
\hline & & $>60$ years & $16(15.09 \%)$ \\
\hline \multirow[t]{3}{*}{3} & \multirow[t]{3}{*}{ Education } & No school & $11(10.38 \%)$ \\
\hline & & senior high school graduates & $26(24.58 \%)$ \\
\hline & & University & $15(14.15 \%)$ \\
\hline \multirow[t]{3}{*}{4} & \multirow[t]{3}{*}{ Occupation } & Civil servants, military, st ate-owned enterprises, national police & $12(11.32 \%)$ \\
\hline & & Private and self-employed & $16(15.10 \%)$ \\
\hline & & Farmers, labors, and handymen & $48(45.28 \%)$ \\
\hline 6 & Smoking habit & Not smoking & $75(70.75 \%)$ \\
\hline \multirow[t]{3}{*}{7} & \multirow[t]{3}{*}{ No pack cigarette/week } & $\geq 15$ packs/weeks & $17(16.05 \%)$ \\
\hline & & $<15$ packs/weeks & $14(13.20 \%)$ \\
\hline & & No smoking & $75(70.75 \%)$ \\
\hline \multirow[t]{3}{*}{8} & \multirow[t]{3}{*}{ Duration of smoking } & $\geq 20$ year & $23(21.70 \%)$ \\
\hline & & $<20$ year & $8(7.55 \%)$ \\
\hline & & No smoking & $75(70.75 \%)$ \\
\hline
\end{tabular}

Table 3. Laboratory examination of healthy volunteers in Yogyakarta

\begin{tabular}{ccc}
\hline No & Characteristics of respondents & Mean \pm SD \\
\hline 1 & Age (year) & $50.76 \pm 32$ \\
2 & Weight (Kg) & $57.62 \pm 9.01$ \\
3 & Height $(\mathrm{cm})(\mathrm{Kg} / \mathrm{cm} 2)$ & $160.55 \pm 4.63$ \\
4 & Body mass index $(\mathrm{BMI})(22.33 \pm 3.27$ \\
5 & Systolic blood pressure $(\mathrm{mmHg})$ & $122.41 \pm 21.49$ \\
6 & Diastolic blood pressure $(\mathrm{mmHg})$ & $80.11 \pm 11.89$ \\
7 & Hemoglobin levels $(\%)$ & $11.91 \pm 1.89$ \\
8 & Erythrocyte counts $(106)(\mathrm{cell} / \mathrm{dl})$ & $4.57 \pm 0.62$ \\
9 & Leukocyte counts $(103)(\mathrm{cell} / \mathrm{dl})$ & $9.58 \pm 4.75$ \\
10 & Platelet counts $(103)(\mathrm{cell} / \mathrm{dl})$ & $255.42 \pm 105.73$ \\
11 & Hematocrit levels & $34.89 \pm 5.76$ \\
12 & Blood sugar levels $(\mathrm{mg} / \mathrm{ml})$ & $116.86 \pm 38.26$ \\
13 & Triglyceride levels $(\mathrm{mg} / \mathrm{dl})$ & $122.10 \pm 70.61$ \\
14 & Urea levels $(\mathrm{mg} / \mathrm{dl})$ & $77.53 \pm 74.03$ \\
15 & Creatinine levels $(\mathrm{mg} / \mathrm{dl})$ & $1.16 \pm 0.11$ \\
16 & Nicotine levels $(\mathrm{ng} / \mathrm{ml})$ & $19.34 \pm 18.75$ \\
17 & Treg count $(\%)$ & $24.96 \pm 7.37$ \\
\hline
\end{tabular}

From the study, hemoglobin and hematocrit levels decreased while creatinine levels increased. The hemoglobin $(\mathrm{Hb})$ levels in this study were subnormal. The average values of $\mathrm{Hb}$ are more than $12 \mathrm{~g} / \mathrm{dl}$ in women and more than $13 \mathrm{~g} / \mathrm{dl}$ in men $[34,35]$. Low hemoglobin and hematocrit levels are associated with 
malnutrition and some chronic diseases [36]. Previous studies found that the $\mathrm{Hb}$ for smoker respondents was higher than the Hb level for nonsmoker [12].

The results showed that the Mean nicotine plasma levels in respondents were quite high at 19.34 $\pm 18.75 \mathrm{ng} / \mathrm{ml}$. The results of the study are the following previous studies [37]. It was reported that average plasma nicotine levels in nonsmokers who were not exposed to cigarette smoke were $0.09-0.7 \mathrm{ng} / \mathrm{mL}$, passive smokers $2-10 \mathrm{ng} / \mathrm{ml}$, and active smokers $>10 \mathrm{ng} / \mathrm{ml}$. Researchers in the USA reported that plasma nicotine levels in smokers in the USA ranged 110-494 $\mathrm{ng} / \mathrm{mL}[8,38]$. Many factors can affect the level of nicotine in the blood apart from the number, duration, and smoking method. Food factors, drugs consumed, and biological conditions and individual habits have been proven to influence nicotine levels in the blood, including kidney function disorders. Data from research in Indonesia shows that the average blood cotinine level of respondents withend stage renal disease (ESRD) is higher than non-ESRD, 63.7 \pm 35.1 vs. 23.8 \pm 8.34 $\mathrm{ng} / \mathrm{ml} \mathrm{p}<0.05$ [39].

\subsection{Nicotine level, hemogram, and Treg number based on smoking status}

Table 4 shows differences in several hemograms and blood chemistry parameters between smokers, former smokers, and nonsmoker subjects. Nicotine levels, number of leukocytes, Treg number, and creatinine level were the difference between groups $\mathrm{p}<0.05$. The smoker group's nicotine and creatinine levels and leukocyte numbers were higher than those of the nonsmokers' $\mathrm{p}<0.05$. Erythrocyte, leukocyte, platelets, and urea were relatively similar between smokers and nonsmokers' $\mathrm{p}<0.05$.

Table 4. Hemogram and blood chemistry based on the smoking status of healthy volunteers in Yogyakarta

\begin{tabular}{lccccc}
\hline \multicolumn{1}{c}{ Characteristic } & No smoking $(\mathrm{n}=81)$ & Former smoker $(\mathrm{n}=7)$ & Smoker $(\mathrm{n}=18)$ & Total & $\mathrm{p}$ \\
\hline Nicotine level $(\mathrm{nmol} / \mathrm{dl})$ & $9.76 \pm 4.61$ & $35.8571 \pm 4.29$ & $56.05 \pm 9.69$ & $19.34 \pm 18.77$ & $0.0001^{*}$ \\
$\mathrm{Hb}$ & $12.77 \pm 1.18$ & $13.31 \pm 1.82$ & $13.15 \pm 1.72$ & $12.87 \pm 1.90$ & 0.6 \\
Eritrocytes & $4.53 \pm .0 .63$ & $4.67 \pm .0 .42$ & $4.68 \pm .0 .54$ & $4.56 \pm 0.61$ & 0.5 \\
Leukocytes & $9.83 \pm 4.16$ & $7.58 \pm 3.70$ & $12.33 \pm 6.41$ & $10.11 \pm 4.69$ & $0.04^{*}$ \\
Platelets (x103 cell/dl) & $258.88 \pm 111.85$ & $266.43 \pm 36.99$ & $252.61 \pm 103.03$ & $258.31 \pm 106.48$ & 0.95 \\
Hmt & $38.41 \pm 5.85$ & $40.31 \pm 4.59$ & $40.0222 \pm 5.60$ & $38.8170 \pm 5.73$ & 0.44 \\
Blood Glucose level (mg/dl) & $107.90 \pm 37.48$ & $159.60 \pm 161.711$ & $107.16 \pm 45.69$ & $111.19 \pm 55.40$ & 0.056 \\
CD4CD25 Treg & $26.31 \pm 7.43$ & $22.31 \pm 8.24$ & $20.45 \pm 3.24$ & $25.08 \pm 7.27$ & $0.01 *$ \\
Triglyceride & $121.59 \pm 72.08$ & $133.99 \pm 82.83$ & $118.73 \pm 58.09$ & $121.92 \pm 70.06$ & 0.86 \\
Ureum (mg/dl) & $37.09 \pm 39.73$ & $74.68 \pm 90.49$ & $38.26 \pm 36.04$ & $39.7789 \pm 44.36$ & 0.096 \\
Creatinine(mg/dl) & $0.83 \pm 0.01$ & $1.01 \pm 1.21$ & $0.89 \pm 0.89$ & $1.09 \pm 1.21$ & $0.02^{*}$ \\
GFR & $94.76 \pm 21.56$ & $86.14 \pm 34.35$ & $100.04 \pm 22.21$ & $95.18 \pm 22.23$ & 0.43 \\
\hline
\end{tabular}

Hemogram profile, urea level, and creatinine level in the study were in the normal range. The number of erythrocytes and platelets in the smokers and nonsmokers in this study did not differ. Still, the number of leukocytes in smokers was higher than nonsmokers and statistically significant $\mathrm{p}<0.05$. Previous studies where smokers had higher leukocytes, hemoglobin, and platelets than nonsmokers found different results. In a cross-sectional study in Japan, elevated white blood cell (WBC) counts are significantly associated with active smokers, but not with former smokers [40]. The subjects in this study were healthy subjects at high risk of $\mathrm{CKD}$, and they were different from the Subjects involved in the previous studies [12, 34].

Creatinine and urea levels in smokers and nonsmokers were within normal limits. The study found that smokers had higher creatinine levels than non-smoking $(0.89 \pm 0.67 \mathrm{vs} .0 .83 \pm 0.01 \mathrm{mg} / \mathrm{dl}, \mathrm{p}<0.05$. The previous study shows that the same results also found that smoking intensity was associated with increased creatinine levels [41, 42]. Nicotine levels in the smokers were the highest $(56.05 \pm 9.69 \mathrm{ng} / \mathrm{ml})$, followed by former smokers $(35.8571 \pm 4.29 \mathrm{ng} / \mathrm{ml})$. The lowest was in nonsmokers $(9.76 \pm 4.61 \mathrm{ng} / \mathrm{ml})$; similar to the results, the previous studies also found that the smoker's group had higher nicotine levels than the nonsmoking $(15.74 \pm 4.24$ v. $53.78 \pm 19.91 \mathrm{mg} / \mathrm{dl}) \mathrm{p}<0.05$. Smokers with more than 15 packs/week or smoking for more than 20 years had the highest blood nicotine levels [11, 43].

Tobacco cigarettes and its nicotine content have shown an influence on the immune system [44]. Chronically smoke exposure increases the incidence of hyperuricemia and albuminuria [45]. On the other hand, it decreases the number and activity of CD4Th and CD8 lymphocytes [46]. In the laboratory, it has been shown that cigarette smoke suppresses the expression of Foxp3 in Treg cells, thus decreasing its number/percentage. Treg plays a significant role in the regulation of inflammatory responses and tissue repair after trauma. Treg functions are as protectors of ischemic renal injury IRI kidneys [47]. Based on these results, we suggest that smokers' risk of kidney damage is more significant than nonsmokers' due to a decrease in Treg level. Treg inhibits inflammation response in the natural immune system. In lymphocyte- 
deficient mice with IRI, adoptive Treg administration can protect test animals from kidney damage due to the excessive natural immune response. In normal circumstances, Treg expresses CD25. The administration of CD25 antibody in test animals with IRI has been proven to reduce the number of CD4Foxp3 Treg in the kidney, spleen, and blood. The test animals are more susceptible to damage than the test animals with a sufficient amount of Treg. The prevention of kidney damage due to IRI is more evident in the test animals with complete Treg deficiency administered with IRI. The absence of FOXP3 as a Treg transcription factor leads to the test animals experiencing autoimmune disease and death on the third or fourth week [48].

\subsection{The relationship between behavior smoking with nicotine levels and Treg counts and association nicotine level with Treg number}

We conducted a correlation analysis with the Pearson correlation to determine the correlation between the number of cigarette consumption and smoking duration. Table 5a presents the correlation test results between cigarette consumption and smoking duration with nicotine level and Treg number). Based on Table 5b, nicotine levels are associated with smoking duration and intensity (several packs/week).

Table 5a. The relationship between many cigarette consumptions and the smoking duration with nicotine level and Treg number and the association between nicotine level with Treg number in healthy volunteer in DIY: (a) correlation analysis (Pears on correlation test) of the number of cigarette consumption and duration

\begin{tabular}{|c|c|c|c|}
\hline Characteristics & Parameters & Nicotine levels & Treg levels \\
\hline Total consumption of cigarettes per week (packs/weeks) & Pearson Correlation & 0.631 & -0.238 \\
\hline \multirow{2}{*}{ Smoking duration (years) } & Pearson Correlation & $0.623^{* *}$ & $-0.219^{* *}$ \\
\hline & Sig. (2-tailed) & 0.000 & 0.005 \\
\hline
\end{tabular}

Correlation is significant at the 0.01 level (2-tailed)

Table 5b. The relationship between many cigarette consumptions and the smoking duration with nicotine level and Treg number and the association between nicotine level with Treg number in healthy volunteer in DIY: (b) regression analysis of nicotine level to Treg number test

\begin{tabular}{cc}
\hline Parameters & Association nicotine level - Treg number \\
\hline Beta & -0.268 \\
$\mathrm{p}$ & $0.002 * * *$ \\
\hline$* *$ Correlation is significant at the 0.01 level (2-tailed)
\end{tabular}

Correlation test results show that the cigarette consumption and smoking duration was related to nicotine levels ( $r=0.63$ and $r=0.62, \mathrm{p}=0.000$, positive) and Treg levels ( $r=0.24$ and $r=0.22, \mathrm{p}=0.002$ and $\mathrm{p}=0.005$, negative). In terms nicotine levels, the positive correlation $(r=0.63)$ indicates that the relationship between the cigarette consumption and smoking duration and serum levels of nicotine is solid, unidirectional and statistically significant $\mathrm{p}<0.00$. Moreover, smoking cigarettes or longer smoking habit leads to higher nicotine levels in the blood. The negative correlation between Treg count and the cigarette consumption and smoking duration ( $r=0.24$ and $r=0.22$ ) shows that the relationship is fairly strong but opposite and statistically significant $(\mathrm{p}<0.05)$. The results indicate a positive correlation between smoking intensity and duration and nicotine levels $(\mathrm{p}<0.05)$. In other words, blood nicotine levels can be used as an indicator of smoking intensity and duration. Interestingly, the nonsmokers were found to have a reasonably high nicotine level at $9 \mathrm{nmol} / \mathrm{dl}$. This result shows that exposure to cigarette smoke in non-smoking respondents is high $[49,50]$.

Treg numbers in the population can vary, as biological and environmental factors influence them. Previous studies found that smokers had a lower number of Treg. In this study, CD4CD25T cells in the smokers' group were lower than the non-healthy healthy subjects, statistically significant $(p<0.05)$. The results of this study are consistent with the results of in vivo experimental laboratories, safe in test animals exposed to dimethylbenzantracene (DMBA), one of the carcinogens in cigarettes, having lower Treg counts than in test animals without DMBA exposure. The DMBA is a carcinogen and immunotoxic agent [51, 52]. Treg cells in peripheral blood from allergic or autoimmune disease patients may be lower than peripheral blood numbers in peripheral blood from healthy subjects [27, 53]. Treg expression is a phenotypic signal to the protection of test animals treated with IRI. At the stage of post-ischemic reperfusion, there has been an increased expression of TGF- $\beta$. Apart from being produced by Treg, TGF- $\beta$ and IL-10 are also provided by renal tubular cells damaged by IRI and macrophages. Treg adoptive administration in test animals with IRI has been shown to improve inflammatory reactions and prevent kidney damage. In mice with complete Treg 
deficiency, there is an accumulation of neutrophils and macrophages in the kidney after an IRI. Neutrophils accumulating in the kidney are shown to actively secrete IFN- $\gamma$ resulting in excessive and destructive inflammatory reactions that endanger test animals [54,55]. The administration of adoptive Treg has been proven to inhibit the natural immune response by decreasing the number of neutrophils in the kidney in test animals treated with IRI. Other studies have shown that administering adoptive Treg to burn traumatic can suppress excessive natural immune responses to prevent the death of test animals but maintain their ability to inhibit deaths due to infection [56].

\section{CONCLUSION}

We conclude that smoking behavior is associated with nicotine level, leukocytes number, and Treg and that smoking habits can increase creatinine levels. The smoking number (packs/week) and duration are related to nicotine levels in the blood. Furthermore, the level of nicotine in the blood is related to the Treg count.

\section{ACKNOWLEDGEMENTS} research.

The authors express their gratitude to all respondents who have been willing to volunteer in this

\section{REFERENCES}

[1] A. Ahsan, Interest of Tobacco Facts and Problems in Indonesia 2014/Bunga Rampai Fakta Tembakau dan Permasalahannya di Indonesia 2014. Tobacco Control Support Center - IAKMI, 2014.

[2] J. P. Narain, R. Garg, and A. Fric, "Non-communicable diseases in the South-East Asia Region: Burden, strategies and opportunities," The National Medical Journal of India vol. 24, no. 5, pp. 280-287, 2011.

[3] L. Mihardja, et al., "Prevalence of kidney dysfunction in diabetes mellitus and associated risk factors among productive age Indonesian,” Journal Diabetes Metabolic Disorder., vol. 17, no. 1, pp. 53-61, 2018.

[4] T. Hidayati, A. Akrom, and L. Apriani, "The effect of physical activity on lymphocyte count in smokers who consume black cumin seed (Nigella sativa L.) oil," International Journal of Public Health Science., vol. 9, no. 1, pp. 8-14,2020.

[5] M. B. Reitsma, et al., "Smoking prevalence and attributable disease burden in 195 countries and territories, 19902015: A systematic analy sis from the global burden of disease study 2015," Lancet, vol. 389, no. 10082, pp. 18851906, 2017.

[6] T. Hidayati, A. Adiningrat, and A. Akrom, "Clinical conditions and history of illness among terminal chronic kidney disease patients," International Journal of Public Health Science, vol. 8, no. 4, pp. 385-390, 2019.

[7] C. H. Hong, et al., "Benzopyrene, a major poly aromatic hydrocarbon in smoke fume, mobilizes Langerhans cells and polarizes Th2/17 responses in epicutaneous protein sensitization through the aryl hydrocarbon receptor," International Immunopharmacology, vol. 36, pp. 111-117, 2016.

[8] R. B. Gonçalves, et al., "Impact of smoking on inflammation: Overview of molecular mechanisms," Inflammation Research, vol. 60, no. 5, pp. 409-424, 2011.

[9] M. Hua and P. Talbot, "Potential health effects of electronic cigarettes: A sy stematic review of case reports," Prev. Med. Reports, vol. 4, pp. 169-178, 2016.

[10] G. E. Bekel and G. Thupayagale-Tshweneagae, "Prevalence and associated factors of metabolic syndrome and its individual components among adolescents," International Journal of Public Health Science, vol. 9, no. 1, p. 46-56, 2020.

[11] S. Kalkhoran, N. L. Benowitz, and N. A. Rigotti, "Prevention and Treatment of Tobacco Use: JACC Health Promotion Series," Journal American College Cardiology., vol. 72, no. 9, pp. 1030-1045, 2018.

[12] A. Q. Alkhedaide, "Tobacco smoking causes secondary polycythemia and a mild leukocytosis among heavy smokers in Taif City in Saudi Arabia," Saudi Journal Biological Sciences, vol. 27, no. 1, pp. 407-411, 2019.

[13] T. Hidayati, et al., "Evaluation of black cumin seeds hexane extract as reactive oxygen intermediates (ROI) and phagocytic activity modulator in DMBA inducedrats," Biomedical Research., vol. 28, no. 4, pp. 1755-1760, 2017.

[14] F. Koukouli and J. P. Changeux, "Do Nicotinic Receptors Modulate High-Order Cognitive Processing?," Trends Neurosciences, vol. 43, no. 8, pp. 550-564, 2020.

[15] N. L. Benowitz, J. Hukkanen, and P. Jacob, "Nicotine chemistry, metabolism, kinetics and biomarkers," Handbook of Experimental Pharmacology, vol. 192. pp. 29-60, 2009.

[16] F. S. AlQahtany, et al., "Association between cigarette \& shisha smoking and the severity of poly cy themia: A cross sectional study," Saudi Journal Biological Sciences, vol. 27, no. 1, pp. 460-464, 2019.

[17] Z. Verde, et al., "Association of HTR2A-1438G/A Genetic Poly morphism with Smoking and Chronic Obstructive Pulmonary Disease,” Archivos Bronconeumologia., vol. 55, no. 3, pp. 128-133, 2019.

[18] P. Formanek, E. Salisbury-Afshar, and M. Afshar, "Helping Patients With ESRD and Earlier Stages of CKD to Quit Smoking,” American Journal of Kidney Diseases, vol. 72, no. 2, pp. 255-266, 2018. 
[19] T. Hidayati, et al., "Chemopreventive effect of black cumin seed oil (BCSO) by increasing p53 expression in dimethylbenzanthracene (DMBA)-induced Sprague Dawley rats," Research Journal Chemistry Environment, vol. 23, no. 8, pp. 24-32, 2019.

[20] P. P. Trihono, L. Rhodia, and M. R. Kary anti, "Kidney Disease Profiles Among Adolescents in Indonesia," Acta Medica Indonesiana, vol. 50, no. 4, pp. 283-290, 2018.

[21] S. J. Elliot, et al., "Smoking induces glomerulosclerosis in aging estrogen-deficient mice through cross-talk between TGF- $\beta 1$ and IGF-I signaling pathway s," Journal American Society Nephrology, vol. 17, no. 12, pp. 33153324, 2006.

[22] B. Bikbov, et al., "Global, regional, and national burden of chronic kidney disease, 1990-2017: a systematic analy sis for the Global Burden of Disease Study 2017," Lancet, vol. 395, no. 10225, pp. 709-733, 2020.

[23] A. B. Fogo, "Mechanisms of progression of chronic kidney disease," Pediatric Nephrology, vol. 22, no. 12. pp. 2011-2022, 2007.

[24] T. Hidayati, et al., "The Insulin Like Growth Factor-1(IGF-1) and Insulin Binding Protein-3 (IGFBP-3) Level As Predictor Biomarker of Chronic Kidney Disease (CKD) Patients in Indonesia," Journal Medical Bioengineering., vol. 4, no. 3, pp. 254-258, 2015.

[25] M. Evans, et al., "Risk Factors for Prognosis in Patients with Severely Decreased GFR," Kidney International Reports, vol. 3, no. 3, pp. 625-637, May 2018.

[26] J. Zhang, et al., "Regulatory $\mathrm{T}$ cells/T-helper cell 17 functional imbalance in uraemic patients on maintenance haemodialysis: A pivotal link between microinflammation and adverse cardiovascular events: Original Article," Nephrology, vol. 15, no. 1, pp. 33-41, 2010.

[27] L. Liu, et al., "Absolute of CD4 +CD25 +FOXP3 + regulatory T-cell count rather than its ratio in peripheral blood is related to long-term survival of renal allografts," in Transplantation Proceedings, 2012, vol. 44, no. 1, pp. $284-$ 286.

[28] T. Hidayati, et al., "Black cumin seed oil increase leucocyte and CD4 Thelper number in sprague-dawley rats induced with dimethylbenzanthracene," International Journal of Public Health Science, vol. 8, no. 2, pp. 238-245, 2019.

[29] W. Prodjosudjadi, et al., "Detection and prevention of chronic kidney disease in Indonesia: Initial community screening," Nephrology, vol. 14, no. 7, pp. 669-674, 2009.

[30] T. Hidayati, S. H. Kushadiwijaya, "Relationship between Hypertension, Smoking And Supplement Energy Drink and the Prevalence of Chronic Kidney Diseases/Hubungan antara hipertensi, merokok dan minuman suplemen energi dan kejadian penyakit ginjal kronik," Berita Kedokteran Masyarakat, vol. 24, no. 2, pp. 90-102, 2008.

[31] M. Chełchowska, et al., "Influence of active exposure to Tobacco smoke on nitric oxide status of pregnant women," International Journal Environmental Research Public Health, vol. 15, no. 12, 2018.

[32] P. Harimurti, J. Prawira, and K. Hort, "The Republic of Indonesia Health System Review," Asia Pacific Observatory on Health Systems and Policies, vol. 7, no. 1, 2017.

[33] R. D. Semba, et al., "Paternal smoking is associated with increased risk of child malnutrition among poor urban families in Indonesia," Public Health Nutrition., vol. 10, no. 1, pp. 7-15, 2007.

[34] K. M. Pedersen, et al., "Smoking and Increased White and Red Blood Cells: A Mendelian Randomization Approach in the Copenhagen General Population Study," Arteriosclerosis, Thrombosis, and Vascular Biology, vol. 39, no. 5, pp. 965-977, 2019.

[35] A. R. Iskandar, et al., "A systems toxicology approach for comparative assessment: Biological impact of an aerosol from a candidate modified-risk tobacco product and cigarette smoke on human organotypic bronchial epithelial cultures," Toxicology in Vitro, vol. 39, no. 2017, pp. 29-51, 2017.

[36] S. Gupta, P. Pingali, and P. Pinstrup-Andersen, "Women's empowerment and nutrition status: The case of iron deficiency in India," Food Policy, vol. 88, no. August, p. 101763, 2019.

[37] A. Chen, et al., "Sex/Gender Differences in Cotinine Levels among Daily Smokers in the Pennsylvania Adult Smoking Study," Journal of Women's Health., vol. 26, no. 11, pp. 1222-1230, 2017.

[38] C. Clair, et al., "Relationships of cotinine and self-reported cigarette smoking with hemoglobin A 1cin the U.S.: Results from the National Health and Nutrition Examination Survey, 1999-2008," Diabetes Care, vol. 34, no. 10, pp. 2250-2255, 2011.

[39] T. Hiday ati, et al., "The Insulin Like Growth Factor-1(IGF-1) and Insulin Binding Protein-3 (IGFBP-3) Level As Predictor Biomarker of Chronic Kidney Disease (CKD) Patients in Indonesia," Journal Medical Bioengineering., vol. 4, no. 3, pp. 254-258, 2015.

[40] T. Higuchi, et al., "Current cigarette smoking is a reversible cause of elevated white blood cell count: Crosssectional and longitudinal studies," Preventive Medicine Reports, vol. 4, pp. 417-422, 2016.

[41] T. Hidayati, H. Purnomo, "Relationship between hypertension, smoking and supplemental drinks with the incidence of ESRD in PKU Muhammadiyah General Hospital Yogyakarta/Hubungan hipertensi minuman suplemen energi dan merokok dengan kejadian penyakit ginjal kronik yang menjalani Hemodialisis di RSU PKU Muhammadiyah Yogyakart)," Thesis, Master Program in Public Health Sciences, Gadjah Mada University, Yogy akarta, Indonesia, 2007.

[42] O. I. Ameh, U. E. Ekrikpo, and A. P. Kengne, "Preventing CKD in Low- and Middle-Income Countries: A Call for Urgent Action," Kidney International Reports, vol. 5, no. 3, pp. 255-262, 2020.

[43] H. R. Middlekauff, J. Park, and R. S. Moheimani, "Adverse effects of cigarette and noncigarette smoke exposure on the autonomic nervous system: Mechanisms and implications for cardiovascular risk," Journal American College Cardiology, vol. 64, no. 16, pp. 1740-1750, 2014. 
[44] M. Sopori, "Effects of cigarette smoke on the immune system," Nature Reviews Immunology., vol. 2, no. 5, pp. 372-377, 2002

[45] D. Dunkler, et al., "Population-Attributable Fractions of Modifiable Lifestyle Factors for CKD and Mortality in Individuals with Type 2 Diabetes: A Cohort Study," American Journal of Kidney Diseases., vol. 68, no. 1, pp. 2940, 2016

[46] A. Tamimi, D. Serdarevic, and N. A. Hanania, "The effects of cigarette smoke on airway inflammation in asthma and COPD: Therapeutic implications," Respiratory Medicine., vol. 106, no. 3, pp. 319-328, 2012.

[47] G. R. Kinsey, et al., "Regulatory T cells suppress innate immunity in kidney ischemia-reperfusion injury," Journal American Society Nephrology., vol. 20, no. 8, pp. 1744-1753, 2009.

[48] N. H. R. Litjens, et al., "Natural regulatory T cells from patients with end-stage renal disease can be used for largescale generation of highly suppressive alloantigen-specific Tregs," Kidney International, vol. 91, no. 5, pp. 12031213, 2017.

[49] J. Xia, et al., "Cigarette smoking and chronic kidney disease in the general population: A systematic review and meta-analysis of prospective cohort studies," Nephrology Dialysis Transplantation., vol. 32, no. 3, pp. 475-487, 2017.

[50] X. Lan, et al., "Nicotine induces podocyte apoptosis through increasing oxidative stress," PLoS One, vol. 11, no. 12, pp. 1-17, 2016.

[51] J. Parmar, P. Sharma, P. Verma, P. Sharma, P.K.Goyal, and I. J. C. B. P. Res., "Modulation of DMBA - induced biochemical and histopathological changes by Syzygium cumini seed extract during skin carcinogenesis," International Journal of Current Biomedical and Pharmaceutical Research (IJCBPR) vol. 1, no. 2, pp. 24-30, 2011.

[52] J. Gao, et al., "p53 and ATM/ATR regulate 7.12-dimethylbenz[a]anthracene-induced immunosuppression," Molecular Pharmacology, vol. 73, no. 1, pp. 137-46, 2008.

[53] U. K. Liyanage, et al., "Prevalence of Regulatory T Cells is Increased in Peripheral Blood and Tumor Microenvironment of Patients with Pancreas or Breast Adenocarcinoma," Journal of Immunology, vol. 169, no. 5, pp. 2756-2761, 2002.

[54] G. Cheng, A. Yu, and T. R. Malek, "T-cell tolerance and the multi-functional role of IL-2R signaling in Tregulatory cells," Immunology Reviews, vol. 241, no. 1, pp. 63-76, 2011.

[55] M. Kassan, et al., "Interleukin-10 released by CD4 +CD25 + Natural regulatory T cells improves microvascular endothelial function through inhibition of NADPH oxidase activity in hypertensive mice," Arteriosclerosis, Thrombosis, and Vascular BiologyBiol., vol. 31, no. 11, pp. 2534-2542, 2011.

[56] D. Q. Tran, "TGF- $\beta$ : The sword, the wand, and the shield of FOXP3 + regulatory T cells," Journal of Molecular Cell Biology, vol. 4, no. 1. pp. 29-37, 2012. 